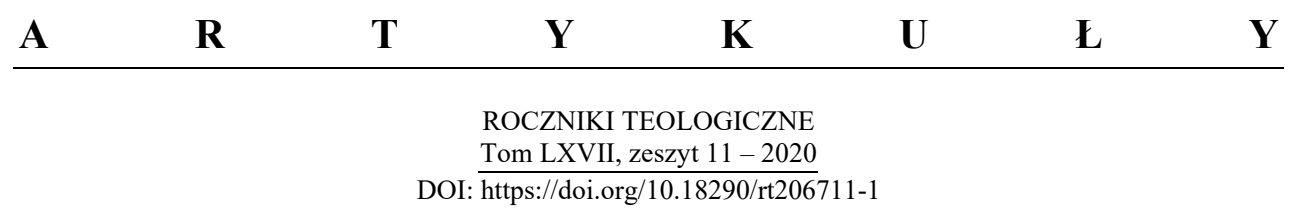

KS. ANDRZEJ KICIŃSKI

\title{
ROZWÓJ DYREKTORIÓW KATECHETYCZNYCH PO SOBORZE WATYKAŃSKIM II (1971-1997-2020)
}

\author{
THE DEVELOPMENT OF CATECHETICAL DIRECTORIES \\ AFTER THE SECOND VATICAN COUNCIL \\ (1971-1997-2020)
}

\begin{abstract}
A b stract. On 23 March 2020, Pope Francis approved a new Directory for Catechesis, which was prepared by the Pontifical Council for Promoting the New Evangelization. The first Directorium Catechisticum Generale of 1971 responded to the great ecclesial event of the Second Vatican Council and its general reform and renewal. The subsequent catechetical documents also responded to the signs of the times in a rapidly changing world, continuing the main message. The Second General Directory for Catechesis of 1997 drew on synods, which emphasised the importance of catechesis, and especially the John Paul II's Exhortation Catechesi tradendae (1979) and the publication of the Catechism of the Catholic Church (1992) had a decisive role in the new development of the objectives, contents and methodological issues. The third Directory for Catechesis of 2020 is a dynamic elaboration on the two previous texts maintaining continuity with them. It is also a reading of contemporary signs of the times.

The Directory is a normative ecclesial document that contains fundamental theological-pastoral principles drawn mainly from the documents of the Second Vatican Council, the Catechism of the Catholic Church, and other documents of the Church's Magisterium in the area of catechesis, as well as general guidelines for episcopates to develop national catechetical directories which, while taking into account specific conditions, will guide the path of catechetical ministry in particular Churches. Their development after the Second Vatican Council marks the transition to the next stage of the proclamation of the Gospel in the modern world.
\end{abstract}

Keywords: Catholic Church; catechetics; pastoral theology; religious education; Christian education; new Directory for Catechesis.

Ks. dr hab. ANDRZEJ KicIŃSKI, prof. KUL, Kierownik Katedry Katechetyki Szczegółowej; adres do korespondencji: Al. Racławickie 14, 20-950 Lublin; e-mail: andrzej.kicinski@kul.pl; ORCID: https://orcid.org/0000-0003-3076-6878. 
Powstanie i rozwój dyrektoriów katechetycznych wiąże się z decyzją ojców soborowych, zawartą w Dekrecie o pasterskich zadaniach biskupów z dnia 28 października 1965 r., która zaleciła stworzenie dyrektorium, mającego pomóc biskupom, a także proboszczom, w sprawowaniu ich urzędu w zakresie katechizacji. Pierwsze dyrektorium po Soborze Watykańskim II ukazało się w 1971, drugie w 1997, a trzecie w 2020 r.

Pierwsze dyrektorium zostało przetłumaczone na język polski pod nazwą Ogólna Instrukcja Katechetyczna ${ }^{1}$, choć dobrze, że niektórzy pozostawili łacińską wersję tytułu, tj. Directorium Catechisticum Generale. Niejasności związane z tłumaczeniem nazwy tego dokumentu mają również źródło w nieprecyzyjnym tłumaczeniu dokumentów soborowych, a także w zrozumieniu roli tego przełomowego dokumentu. Oryginalny tekst łaciński dekretu obejmuje zarządzenie, aby sporządzić „Directorium de catechetica populi christiani institutione” (DB 44). Inne tłumaczenia też używają terminu „dyrektorium”. I tak po włosku chodzi o ,un direttorio per l'istruzione catechistica del popolo”, po angielsku mamy „directory [...] concerning the catechetical instruction of the Christian people”, po niemiecku - „ein Direktorium für die katechetische Unterweisung des christlichen Volkes”, po francusku - „un directoire sur l'enseignement catéchétique du peuple chrétien”, a po hiszpańsku - „directorio sobre la instrucción catequética del pueblo cristiano". Natomiast pierwsze tłumaczenie soborowych dokumentów na język polski, które ukazało się drukiem w dwa lata po zakończeniu Vaticanum II, analizowany tekst oddało następująco: „należy również sporządzić [...] poradnik katechetycznego nauczania ludu chrześcijańskiego” [podkr. A.K.]². Termin „poradnik” w języku polskim kojarzy się bezpośrednio z radami i informacjami, a nie normami wypływającymi z rangi „dyrektorium”. Bliższe już jest - choć jeszcze zawęża znaczenia tego dokumentu - nowe tłumaczenie dokumentów soborowych, które ukazało się po ponad 30 latach od pierwszego i zostało zatwierdzone w roku 2002. Tłumaczenie to brzmi, że należy sporządzić: „wytyczne do

\footnotetext{
${ }^{1}$ Kongregacja DS. Duchowieństwa, Directorium Catecheticum Generale, Vaticano 1971. Wyd. polskie: Ogólna Instrukcja Katechetyczna, w: „Wiadomości Archidiecezji Warszawskiej” 63(1973), nr 2, s. 37-112. Dostępne są tylko inicjały tłumacza X.E.SZ. Ta wersja thumaczenia była przedrukowywana w kilku diecezjach w oddzielnym druku zwartym pod dwoma tytułami: Ogólna Instrukcja Katechetyczna z dodanym podtytułem Directorium Catecheticum Generale. Ukazała się również jako Ogólna Instrukcja Katechetyczna, w: Katecheza po Soborze Watykańskim II w świetle dokumentów Kościoła, red. W. Kubik, tom 1, s. 91-192, ale bez „wykazu najważniejszych skrótów" (dalej DCG).

${ }^{2}$ Dekret o pasterskich zadaniach biskupów w Kościele, w: SOBÓR WATYKAŃSKI II, Konstytucje, dekrety, deklaracje. Tekst polski, red. J. Groblicki, E. Florkowski, S. Jaworski, L. Krawczyk, Poznań 1967, nr 44.
} 
katechetycznego nauczania ludu chrześcijańskiego" [podkr. A.K.] ${ }^{3}$. Rozumiał trudności semantyczne i pragmatyczne thumacz pierwszego dyrektorium na język polski i zamiast terminu „poradnik” użył już słowa „,instrukcja”, aby lepiej oddać znaczenie dokumentu. Niniejszy artykuł ma na celu odpowiedzenie na pytania: Jaka jest geneza powstania i charakterystyka dyrektoriów katechetycznych? Dlaczego ukazują się nowe? Co znaczą posoborowe dyrektoria katechetyczne dla rozwoju myśli i praktyki katechetycznej? I jak można dziś zdefiniować dyrektorium katechetyczne? W przypisach opracowane zostaną sylwetki osób, które kierowały procesem powstania dokumentów katechetycznych.

\section{DIRECTORIUM CATECHISTICUM GENERALE Z 1971 ROKU}

Directorium Catechisticum Generale wraz z dodatkiem o pierwszej spowiedzi i komunii świętej zatwierdził Paweł VI 18 marca 1971 r. i promulgował 11 kwietnia tego samego roku w Rzymie w dniu Zmartwychwstania Pańskiego. Dyrektorium wydane przez Kongregację ds. Duchowieństwa zostało podpisane przez pro-prefekta kard. Johna Wrighta ${ }^{4}$ i sekretarza tejże Kongregacji abp. Pietro Palazziniego ${ }^{5}$.

\footnotetext{
${ }^{3}$ Dekret o pasterskich zadaniach biskupów w Kościele, w: SOBÓR WATYKAŃSKI II, Konstytucje, dekrety, deklaracje. Tekst polski. Nowe tlumaczenie, red. M. Przybył, Poznań 2002, nr 44. Problem nowego tłumaczenia dotyka dalej innych dokumentów o randze dyrektoriów i ich definicji: „Ponadto święty Sobór postanawia, aby sporządzono ogólne wytyczne duszpasterskie [«dei direttori generali», czyli dyrektoriów ogólnych - A.K.], tak na użytek biskupów, jak i proboszczów, celem dostarczenia konkretnych wskazówek [«nell'intento di fornire loro norme e metodi per esercitare più adeguatamente e più facilmente il loro ministero pastorale», czyli nie tylko chodzi o konkretne wskazówki, ale o normy i wskazania - A.K.] do łatwiejszego i lepszego wypełniania zadań pasterskich. Należy również sporządzić wytyczne duszpasterskie dotyczące specjalnych grup wiernych, stosownie do różnych uwarunkowań poszczególnych narodów lub regionów, oraz wytyczne do katechetycznego nauczania ludu chrześcijańskiego, w którym chodziłoby o podstawowe zasady i organizację tegoż nauczania, a także o opracowanie książek przeznaczonych do tego celu. Przy sporządzaniu tych wytycznych winno się również wziąć pod uwagę spostrzeżenia, które zostały przedstawione przez komisję albo przez Ojców soborowych" (CD 44).

${ }^{4}$ Kardynał John Joseph Wright (ur. 18 lipca 1909 w Dorchester w USA, zm. 10 sierpnia 1979 w Cambridge w USA). W latach 1969-1979 (do śmierci) pełnił funkcję prefekta Kongregacji Duchowieństwa. 11 kwietnia 1971 r. w Rzymie, w Zmartwychwstanie Pańskie jako prefekt Kongregacji podpisał wraz z ówczesnym abp. Pietro Palazzinim pierwsze Directorium Catechisticum Generale zatwierdzone przez Pawła VI. Wcześniej studiował na Papieskim Uniwersytecie Gregoriańskim w Rzymie (licencjat uzyskał w 1936 roku, a doktorat z teologii w 1939 r.). W latach 1939-1943 nauczał filozofii i teologii w macierzystej uczelni Seminarium Św. Jana w Brighton aż do 1943, kiedy został mianowany prywatnym sekretarzem kardynała arcybiskupa Bostonu, Williama O’Connella. W 1947 roku został mianowany biskupem pomocniczym w Bostonie. W 1959 r.
} 
Jan Paweł II przypomniał w adhortacji Catechesi tradendae, że Paweł VI nazwał dokumenty Soboru Watykańskiego II „wielkim katechizmem naszych czasów" (CT 2). Geneza pierwszego oficjalnego tekstu poświęconego katechezie sięga więc do nauczania Soboru Watykańskiego II i jego decyzji o konieczności opracowania dyrektorium katechetycznego. Kongregacja ds. Duchowieństwa rozesłała po soborze kwestionariusz w tej kwestii do poszczególnych konferencji episkopatów i po zebraniu opinii powołała w 1968 roku specjalną komisję ekspertów z zakresu katechetyki. Zespół ten opracował i przedstawił pierwszy schemat dyrektorium w 1969 roku, który został przesłany do zaopiniowania przez konferencje episkopatów. Po zapoznaniu się z sugestiami i opiniami komisja ekspertów opracowała pełny projekt dyrektorium i przekazała tekst do specjalnej komisji teologów, która naniosła własne poprawki i dodała addendum w postaci suplementu o przygotowaniu do pierwszej spowiedzi i komunii świętej. Ostatnim etapem prac było naniesienie kolejnych poprawek i przedstawienie dyrektorium do ostatecznej aprobaty przez Kongregację Nauki Wiary.

Pierwsze Directorium Catechisticum Generale składało się z wprowadzenia, sześciu części, dwunastu rozdziałów i dodatku.

został mianowany biskupem Pittsburgha. W latach 1962-1965 uczestniczył w II Soborze Watykańskim, podczas którego miał duży wpływ na powstanie kilku dokumentów soborowych. 23 kwietnia 1969 roku Paweł VI mianował Wrighta prefektem Kongregacji Duchowieństwa. W owym czasie był najwyższym rangą amerykańskim kardynałem w Kurii Rzymskiej.

${ }^{5}$ Kardynał Pietro Palazzini (ur. 9 maja 1912 w Piobbico, diecezja Cagli we Włoszech, zm. 11 października 2000 w Rzymie). 11 kwietnia 1971 r. w Rzymie, w Zmartwychwstanie Pańskie jako ówczesny abp i sekretarz wraz z kard. J. Wrightem podpisał pierwsze Directorium Catechisticum Generale zatwierdzone przez Pawła VI. Kard. Palazzini studiował w Regionalnym Seminarium św. Piusa XI w Fano oraz na uczelniach rzymskich - Papieskim Athenaeum Laterańskim i Papieskim Seminarium Rzymskim. Od 1942 związany był z rzymskimi uczelniami katolickimi jako wicerektor Papieskiego Seminarium Rzymskiego, wicerektor i kwestor Papieskiego Athenaeum Św. Apolinarego, wykładowca Papieskiego Athenaeum Laterańskiego i Instytutu „Utriusque Iuris”. W 1956 r. mianowany podsekretarzem Kongregacji Zakonów; od grudnia 1958 sekretarz Kongregacji Soboru. Brał udział w obradach Soboru Watykańskiego II. W 1962 r. mianowany przez Jana XXIII arcybiskupem. W latach 1968-1973 sekretarz w Kongregacji ds. Duchowieństwa. W 1973 mianowany kardynałem przez Pawła VI. Brał udział w obu konklawe 1978; w latach 1980-1988 był prefektem Kongregacji Spraw Kanonizacyjnych. Był inicjatorem prac nad Bibliotheca Sanctorum. W 1983 r. podniesiony do godności kardynała prezbitera. Wielokrotnie uczestniczył w sesjach Światowego Synodu Biskupów. Był autorem wielu publikacji m.in. Morale generale (1961) i Dictionarium morale-canonicum (1962). 
Tabela 1. Struktura DCG z 1971 r.

\begin{tabular}{|c|c|}
\hline Części & Rozdzialy \\
\hline \multicolumn{2}{|l|}{ Wprowadzenie } \\
\hline \multicolumn{2}{|l|}{ I. Aktualność problemu, nr 1-9 } \\
\hline II. Posługa słowa, nr 10-35 & $\begin{array}{l}\text { 1. O posłudze słowa i Objawieniu, nr 10-16 } \\
\text { 2. Katecheza w misji duszpasterskiej Kościoła, nr 17-35 }\end{array}$ \\
\hline $\begin{array}{l}\text { III. Chrześcijańskie orędzie, } \\
\text { nr 36-69 }\end{array}$ & $\begin{array}{l}\text { 1. Normy, czyli kryteria. Przedmiot katechezy w odniesieniu do } \\
\text { różnych form życia kościelnego, różnych kultur } \\
\text { i przeciwstawnych sposobów wyrażania myśli, nr } 37-46 \\
\text { 2. Ważniejsze elementy chrześcijańskiego orędzia. Tajemnica } \\
\text { jedynego Boga: Ojca, Syna i Ducha Świętego, nr 47-69 }\end{array}$ \\
\hline \multicolumn{2}{|l|}{$\begin{array}{l}\text { IV. Elementy metodologii, } \\
\text { nr } 70-76\end{array}$} \\
\hline \multicolumn{2}{|l|}{$\begin{array}{l}\text { V. Katecheza dostosowana do } \\
\text { wieku, nr 77-97 }\end{array}$} \\
\hline $\begin{array}{l}\text { VI. Działalność duszpasterska } \\
\text { przez posługę słowa, } \\
\text { nr } 98-134\end{array}$ & $\begin{array}{l}\text { 1. Analiza sytuacji - cel, nr 99-102 } \\
\text { 2. Plan działania, nr 103-107 } \\
\text { 3. Formacja katechetyczna, nr 108-115 } \\
\text { 4. Pomoce katechetyczne, } \mathrm{nr} 116-124 \\
\text { 5. Organizacja katechezy, nr 125-128 } \\
\text { 6. Koordynacja katechetycznej działalności duszpasterskiej } \\
\text { z ogólną akcją duszpasterską, nr 129-130 } \\
\text { 7. Konieczność prowadzenia badań naukowych, nr } 131 \\
\text { 8. Współpraca międzynarodowa i kontakty ze Stolicą } \\
\text { Apostolską, nr 132-134 }\end{array}$ \\
\hline $\begin{array}{c}\text { Dodatek: Pierwsza spowiedź } \\
\text { i komunia święta }\end{array}$ & \\
\hline
\end{tabular}

Pierwsza część DCG zatytułowana „Aktualność problemu” w dziewięciu numerach dokumentu wprowadza w złożoną działalność wychowawczą Kościoła w okresie posoborowym. Syntetycznie charakteryzuje istotne zagadnienia w kluczu pastoralnym: od strony świata i od strony Kościoła. Trzeba uwzględnić, że dokument ten musiał pogodzić sytuację kościołów lokalnych, gdzie już widoczny był proces odchodzenia od tradycji chrześcijańskiej (Europa Zachodnia) z tymi, którzy cierpieli prześladowania, trzymając się mocno tradycji katolickiej (m.in. Europa Centralna) i z tymi, którzy byli w fazie rozkrzewiania wiary w swoich krajach lub regionach (Afryka). DCG to synteza katechetyczna przesłania Soboru Watykańskiego II, w pierwszej części to analiza nauki zawartej m.in. w konstytucji Gaudium et spes czy deklaracji 
Dignitas humanae, które przeciwstawiały się wszelkiemu minimalizmowi w służbie wiary wyjaśnianej na katechezie.

Druga część, zatytułowana „Posługa Słowa” i obejmująca dwadzieścia sześć numerów, daje syntezę konstytucji Dei Verbum. Trzeba pamiętać, że konstytucja ta otrzymała w nagłówku przymiotnik „dogmatyczna”, stąd pierwszy rozdział „O posłudze słowa i Objawieniu” zawiera bardziej doktrynalne założenia, a drugi rozdział „Katecheza w misji duszpasterskiej Kościoła” ma już charakter duszpasterski i katechetyczny. Jest tam po raz pierwszy zasygnalizowane ważne zagadnienie relacji katechezy i ewangelizacji.

Trzecia część zatytułowana „Chrześcijańskie orędzie” to synteza poświęcona przedmiotowi katechezy, która została zawarta w 34 numerach dokumentu. Właśnie tutaj dobrze widać, jak ważne jest tłumaczenie i zrozumienie terminu „dyrektorium”. Nie jest to prosta instrukcja czy poradnik z radami, czy nawet same wytyczne. Dyrektorium zawiera również ważniejsze prawdy, zawarte w orędziu zbawienia, organicznie ze sobą powiązane. Dyrektorium w tej części mówi, niestety tylko ogólnie, o „głównych błędach współczesnej epoki, ewentualnie tych prawd wiary, które są dzisiaj częściej zaprzeczane lub pomijane" (DCG 36) ${ }^{6}$. Te błędy w katechezie spowodowały, że DCG podkreśla i pogłębia w tej części takie zagadnienia jak to, że ostatecznym celem katechezy jest przedstawienie całej prawdy, że treść katechezy stanowi pewną organiczną i żywą całość, czym jest chrystocentryzm czy teocentryzm trynitarny w katechezie i wiele innych ważniejszych elementów chrześcijańskiego orędzia.

Czwarta część zatytułowana „Elementy metodologii” zawiera tylko siedem numerów dokumentu, w których z jednej strony zauważa się rozwój katechetyki jako dyscypliny naukowej uwzględniającej dorobek psychologów i pedagogów, a z drugiej pozostawia się dużą swobodę poszczególnym narodom $\mathrm{w}$ wyborze adekwatnej metody nauczania/uczenia się. Kluczem do zrozumienia metodologii katechetycznej jest stwierdzenie dotyczące roli katechety: „Żadna metoda, chociażby bardzo potwierdzona doświadczeniem, nie zwalnia katechety z osobistego wysiłku asymilowania i oceny konkretnych okoliczności, jak również odpowiedniego przystosowania się do nich. Najszlachetniejsze

\footnotetext{
${ }^{6}$ Tylko kilku katechetyków podejmuje trud zgłębienia tych błędów w katechezie, np. J. Charytański, który analizując Lineamenta z 1976 wydane przed synodem biskupów poświęconym katechezie zauważył, że dokument „wskazuje na istnienie ujęć ekstremistycznych. Na jednym końcu zdają się umieszczać katechezę klasycznego, doktrynalnego katechizmu, na drugim zaś skrajne ujęcie antropologiczne czy «polityczne» jak np. katecheza wyzwolenia". J. CHARYTAŃSKI, Katecheza Ewangelii $i$ wedlug Ewangelii. Treść katechezy w świetle dokumentów synodalnych, w: Katecheza po Soborze Watykańskim II w świetle dokumentów Kościoła, red. W. Kubik, tom 2, Warszawa 1985, s. 52.
} 
bowiem przymioty ludzkie i chrześcijańskie katechety bardziej gwarantują owocność katechezy aniżeli wyszukane metody" (DCG 71). Przypomina się tutaj również o prymacie łaski Bożej w otwieraniu się katechizowanego na wiarę.

Piąta część zatytułowana „Katecheza dostosowana do wieku” to 21 numerów schematycznie ukazujących „drogi i sposoby przystosowania orędzia do różnych potrzeb ludzkich" (DCG 77). Z pewnością można by rozważać, co znaczy „przystosować orędzie” (,per rendere il messaggio cristiano adatto”), trzeba jednak podkreślić bardzo udaną syntezę rozwoju wiary na poszczególnych etapach rozwojowych i w różnych sytuacjach. Spójny i logiczny wykład o roli życia religijnego i moralnego od wczesnego dzieciństwa, przez całe dzieciństwo, dojrzewanie, okres młodości i dojrzałości, aż po okres starości. DCG zaczęło przełamywać stereotyp, że katecheza to działalność eklezjalna dla dzieci i młodzieży.

Szósta część zatytułowana „Działalność duszpasterska przez posługę słowa” to 37 numerów dokumentu poświęconych przełomowym decyzjom związanym z organizacją działalności katechetycznej. DCG postuluje nie tylko powołanie komisji ds. katechezy przy konferencjach episkopatów, ale również stałego organu wykonawczego. Najważniejsze osiem decyzji można zestawić następująco: 1) przygotowanie raportu na temat katechizacji; 2) przygotowanie całościowego programu katechetycznego; 3) powołanie wyższych instytutów katechetycznych, aby formowały profesjonalnych katechetów; 4) opracowanie krajowego dyrektorium katechetycznego, programów, podręczników i katechizmów oraz pomocy audiowizualnych do katechezy; 5) powołanie krajowych i diecezjalnych struktur katechetycznych; 6) skoordynowanie działalności katechetycznej z duszpasterstwem ogólnym i specjalistycznym; 7) konieczność prowadzenia badań naukowych z zakresu katechetyki; 8) prowadzenie współpracy międzynarodowej, a zwłaszcza współpracy z Kongregacją ds. Duchowieństwa.

Podsumowując te przełomowe decyzje, należy podkreślić, że Konferencja Episkopatu Polski wprowadziła je prawie wszystkie. W sytuacji, w jakiej w ówczesnym czasie znajdował się Kościół katolicki w Polsce, wprowadzenie tych reform było wielkim i opatrznościowym wysiłkiem całej Konferencji Episkopatu Polski ${ }^{7}$. Tylko na polskie dyrektorium katechetyczne przyszło poczekać jeszcze do czasu przemian ustrojowych w Polsce.

\footnotetext{
${ }^{7}$ Warto przy tej okazji przypomnieć osobę abp. Jerzego Strobę, który był przewodniczącym Komisji Katechetycznej KEP (1958-1996) i członkiem Międzynarodowej Rady ds. Katechizacji (COINCAT). Brał czynny udział w soborowych przemianach i był ich promotorem także w Polsce. To abp Stroba podczas konferencji naukowej, która miała miejsce w Lublinie 12 lutego 1964 r., przekazał postulat Komisji Episkopatu ds. Katechizacji, by KUL pilnie rozważył przygotowanie
} 
DCG stało się fundamentalnym dokumentem, które przeniosło nauczanie Soboru Watykańskiego II na teren katechetyki i katechezy. Oczywiście samo dyrektorium było owocem długiego procesu soborowych przemian. Nie wszyscy chcieli, aby ono stało się dokumentem uniwersalnym i normatywnym, obawiając się, że może narzucać pewne rozwiązania odległe praktyce katechetycznej w poszczególnych Kościołach partykularnych. Trzeba pamiętać, że Francuzi mieli już Directoire de Pastoral Catéchètique à l'usage des diocèses de France wydane w 1964 i inne dokumenty katechetyczne. Holendrzy mieli dokument Grondlijnen voor een vernieuwde schoolkatechese, który również ukazał się w 1964 r., stając się przełomowym zwrotem soborowym i doprowadzając do powstania znanego katechizmu holenderskiego, w Polsce mocno i raczej jednostronnie krytykowanego ${ }^{8}$. Także Włosi mieli już własne dyrektorium pt. Il rinnovamento della catechesi. Documento Base, opublikowane w 1970 r. Podobne dokumenty mieli również Niemcy (1971-1975), czy niektóre kraje Ameryki Łacińskiej (Argentyna w 1967, a Meksyk w 1971 r.) ${ }^{9}$. Ukazanie się DCG w 1971 r. stało się jednak przełomowe, bowiem po raz pierwszy w dziejach Kościoła zostało opublikowane kompendium zasad i norm teologicznych oraz metodologiczno-pastoralnych dla katechezy, które ukierunkowywało i koordynowało działania pastoralno-katechetyczne w całym Kościele. Wraz z ukazaniem się dyrektorium rozpoczął się długi proces odnowy katechetycznej związanej z Soborem Watykańskim II, ale również rozpoczął się

nowych kadr katechetycznych. W konferencji brał udział: ks. Marian Rechowicz - rektor KUL, o. Andrzej Ludwik Krupa - dziekan Wydziału Teologii, ks. Władysław Poplatek - prodziekan Wydziału i opiekun Sekcji Teologii Pastoralnej, ks. Ignacy Tokarczuk - adiunkt przy Sekcji Teologii Pastoralnej, ks. Franciszek Blachnicki - asystent przy Sekcji Teologii Pastoralnej. Wnioski i postulaty zostały przeanalizowane podczas Rady Wydziału Teologii KUL 14 grudnia 1964 r., uzyskując aprobatę. Uchwalono wówczas, by rozszerzyć, unowocześnić i nadać trwały charakter Sekcji Teologii Pastoralnej, która istniała od 1958 r., ale bez katechetyki. Od 1964 r. w skład sekcji weszła specjalizacja pedagogiczno-katechetyczna. Zorganizowanie specjalizacji powierzono ks. F. Blachnickiemu. Opracował on pierwszy projekt wykładów, seminariów i ćwiczeń. Pierwszymi pracownikami katechetyki byli ks. F. Blachnicki (katechetyka fundamentalna), ks. Jan Charytański dojeżdżający z Warszawy (katechetyka materialna) i ks. Edward Materski (dydaktyka katechezy). Praktyka katechetyczna w Polsce wyprzedziła więc ukazanie się DCG i podjęto wcześniej badania naukowe z katechetyki i formację katechetów. DCG po ukazaniu się w $1971 \mathrm{r}$. stało się stałym punktem odniesienia $\mathrm{w}$ badaniach katechetyki posoborowej i motorem napędowym w uniwersyteckiej formacji katechetów w Polsce.

${ }^{8}$ Po ukazaniu się katechizmu holenderskiego pojawiły się kontrowersje związane z pewnymi błędami. Stolica Święta mianowała komisję kardynałów i zespół teologów, którzy po spotkaniach z biskupami holenderskimi i zespołem redakcyjnym uzupełnili publikację, którą ostatecznie Stolica Apostolska zatwierdziła.

${ }^{9}$ Szerzej o wcześniejszych dyrektoriach krajowych, zob. E. AlBERICH, Dyrektoria katechetyczne krajowe, w: Stownik katechetyczny, red. J. Gevaert, K. Misiaszek, Warszawa 2007, s. 226-229. 
proces usystematyzowania dorobku naukowego w tym obszarze. Dzięki dyrektorium otrzymaliśmy autorytatywny punkt odniesienia, zarówno co do treści katechetycznych, jak i wskazań metodologicznych, czy też organizacyjnych.

\section{DYREKTORIUM O KATECHIZACJI Z 1997 ROKU}

Dyrektorium Ogólne o Katechizacji ${ }^{10}$ zostało zaaprobowane przez Jana Pawła II i opublikowane przez Kongregację ds. Duchowieństwa w dniu Wniebowzięcia NMP 15 sierpnia 1997 r. DOK podpisał pro-prefekt Kongregacji abp Darío Castrillón Hoyos ${ }^{11}$ i sekretarz abp Crescenzio Sepe ${ }^{12}$. Uroczyste

${ }^{10}$ Kongregacja DS. Duchowieństwa, Direttorio Generale per la Catechesi, Vaticano 1997. Kongregacja wydała również polską wersję językową: Dyrektorium ogólne o katechizacji, Poznań 1998. Nie podano tłumacza, lecz tłumaczenia najczęściej wykonywane były przez pracowników Kongregacji albo zlecano to zadanie Polakom współpracującym ze Stolicą Apostolską. W 1998 r. wydawnictwo Pallottinum wydało poprawioną wersję językową - również bez podania nazwiska thumacza (dalej: DOK).

${ }^{11}$ Kardynał Darío Castrillón Hoyos (ur. 4 lipca 1929 w Medellín w Kolumbii, zm. 18 maja 2018 w Rzymie). Castrillón Hoyos podpisał 15 sierpnia 1997 r. w Rzymie jako Pro-prefekt Kongregacji wraz z ówczesnym sekretarzem abp. Crescenzo Sepe, drugie Dyrektorium Ogólne o katechizacji zatwierdzone przez Jana Pawła II. Wcześniej studiował w seminarium w Antioquia i Santa Rosa de Osos, święcenia kapłańskie przyjął w 1952 r. w Rzymie. Kontynuował studia w Rzymie, na Papieskim Uniwersytecie Gregoriańskim obronił doktorat z prawa kanonicznego; ponadto studiował na Wydziale Socjologii Uniwersytetu Katolickiego w Louvain (Belgia). Po powrocie do Kolumbii pracował jako duszpasterz. Zajmował się również problematyką katechetyczną oraz pełnił funkcję sekretarza generalnego Episkopatu Kolumbii. W latach 1971-1976 biskup koadiutor Pereira. W latach 1976-1992 ordynariusz Pereira. W latach 1983-1987 sekretarz generalny, a w latach 1987-1991 przewodniczący Rady Episkopatów Latynoamerykańskich CELAM (brał udział w IV konferencji generalnej Episkopatów Latynoamerykańskich w Santo Domingo w październiku 1992). W latach 1992-1996 arcybiskup Bucaramanga. W czerwcu 1996 przeszedł do pracy w Kurii Rzymskiej. Został pro-prefektem Kongregacji Duchowieństwa. 21 lutego 1998 r. Jan Paweł II wyniósł go do godności kardynalskiej. Po nominacji kardynalskiej Castrillón Hoyos został pełnoprawnym prefektem Kongregacji Duchowieństwa, a w kwietniu 2000 r. objął dodatkowo funkcję prezydenta Papieskiej Komisji Ecclesia Dei. Obie funkcje pełnił do 31 października 2006 r., kiedy złożył rezygnację w związku z osiągnięciem przez kardynała wieku emerytalnego.

12 Kardynał Crescenzio Sepe (ur. 2 czerwca 1943 w Carinaro w regionie Kampania we Włoszech - obecnie arcybiskup Neapolu). Sepe podpisał 15 sierpnia 1997 r. w Rzymie jako sekretarz Kongregacji wraz z ówczesnym pro-prefektem abp. Darío Castrillón Hoyos drugie Dyrektorium Ogólne o katechizacji zatwierdzone przez Jana Pawła II. Wcześniej studiował w seminariach w Aversa i Salerno, święcenia kapłańskie przyjął w 1967 r. w Aversa. Studia uzupełniał w Rzymie. Na Papieskim Uniwersytecie Laterańskim obronił doktorat z teologii i licencjat z prawa kanonicznego, na Uniwersytecie La Sapienza uzyskał doktorat z filozofii, a na Papieskiej Akademii Duchownej przygotowywał się do pracy w dyplomacji watykańskiej. Po studiach wykładał teologię sakramentalną na Papieskim Uniwersytecie Laterańskim oraz teologię dogmatyczną na Papieskim 
promulgowanie dokumentu miało miejsce podczas Międzynarodowego Kongresu Katechetycznego, który odbył się w Rzymie w dniach 14-17 października 1997 r. DOK od razu został opublikowany w podstawowych językach: łacińskim, włoskim, francuskim, angielskim, niemieckim, hiszpańskim, portugalskim oraz polskim.

Początkowe fazy powstawania dokumentu to rozesłanie kwestionariuszy 30 listopada 1993 r. przez Kongregację ds. Duchowieństwa do konferencji episkopatów, członków Międzynarodowej Rady ds. Katechezy (COINCAT), instytutów katechetycznych i licznych ekspertów. Po zebraniu opinii powstał pewnego rodzaju instrumentum laboris. Podczas obrad dziewiątej sesji COINCAT działającej przy Kongregacji ds. Duchowieństwa, która odbyła się w dniach 20-23 września 1994 r. w Rzymie, powstał schemat oraz kryteria redakcji DOK. 29 listopada 1994 r. bp L. Estepa i ks. prof. C. Bissoli otrzymali od Kongregacji mandat opracowania końcowej rewizji prac. Redakcja tekstu została ukończona w 1995 r. i została ponownie odesłana do oceny konferencjom episkopatów. W lutym 1996 r. rozpoczęły się prace ostateczne, które polegały na zapoznaniu się z uwagami odnośnie tekstu, jak i uwagami z kwestionariusza, który był załączony do niego. Po trzech latach prac ostateczna redakcja została zaaprobowana przez Jana Pawła II.

Nie można jednak dobrze zrozumieć powstania drugiego dyrektorium katechetycznego bez uwzględnienia żywej troski Nauczycielskiego Urzędu Kościoła o katechezę. Odnowa katechetyczna, po ukazaniu się DCG w 1971 r., wzbogaciła się o Obrzędy chrześcijańskiego wtajemniczenia dorostych (1972) czy adhortację Pawła VI Evangelii nuntiandi (1975). Zebrania synodów biskupów wyrastające z inspiracji Soboru Watykańskiego II są bez wątpienia kuźnią nowych idei katechetycznych. Po jednym z takich synodów ukazała się adhortacja Jana Pawła II Catechesi tradendae (1979), a po synodzie w 1987 r. nie tylko ukazała się adhortacja Christifideles laici (1988), ale tam oficjalnie ojcowie synodalni zaproponowali Ojcu Świętemu opracowanie katechizmu

Uniwersytecie Urbaniana. Autor m. in. następujących publikacji: La dimensione trinitaria del carattere sacramentale, Persona e storia. Per una teologia della persona, Rapporto sulla missione i Dio disse: Facciamo l'uomo. Od 1972 pozostawał w służbie dyplomatycznej Stolicy Apostolskiej, był sekretarzem nuncjatury w Brazylii. Od 1975 pracował w centrali Sekretariatu Stanu, początkowo w sekcji organizacji międzynarodowych, potem w biurze informacji i dokumentacji. W latach 1987-1992 pełnił funkcję asesora ds. ogólnych w Sekretariacie Stanu. Od 2 kwietnia 1992 do 3 listopada 1997 był sekretarzem Kongregacji ds. Duchowieństwa. Od listopada 1997 pełnił funkcję sekretarza generalnego Komitetu Centralnego Obchodów Wielkiego Jubileuszu Roku 2000 oraz prezydenta instytucji Peregrinatio ad Petri Sedem. 21 lutego 2001 r. Jan Paweł II mianował go kardynałem. W latach 2001-2006 był prefektem Kongregacji Ewangelizacji Narodów. Od 2006 jest arcybiskupem Neapolu. W 2005 i 2013 r. uczestniczył w konklawe. 
uniwersalnego dla Kościoła katolickiego, który jako Katechizm Kościoła Katolickiego został ogłoszony za pośrednictwem konstytucji apostolskiej Fidei depositum 11 października 1992 r.

Directorium Catechisticum Generale zostaje zastąpione przez dokument o bardzo podobnej nazwie Direttorio Generale per la Catechesi i zachowując podstawową strukturę tekstu i terminologię z $1971 \mathrm{r}$. uwzględnia dwa nowe wymagania. Po pierwsze ukierunkował katechezę w ramach ewangelizacji na podstawie adhortacji Evangelii nuntiandi i Catechesi tradendae. Po drugie uwzględnił treści wiary zaproponowane przez Katechizm Kościoła Katolickiego.

Drugie dyrektorium katechetyczne składało się ze wstępu, wprowadzenia, pięciu części, szesnastu rozdziałów, zakończenia i indeksu tematycznego.

Tabela 2. Struktura DOK z 1997 r.

\begin{tabular}{|c|c|}
\hline Części & Rozdziały \\
\hline Wstęp, nr 1-13 & \\
\hline $\begin{array}{l}\text { Wprowadzenie: Głoszenie } \\
\text { ewangelii w świecie współ- } \\
\text { czesnym, nr 14-33 }\end{array}$ & \\
\hline $\begin{array}{l}\text { I. Katecheza w misji ewangeli- } \\
\text { zacyjnej Kościoła, nr 34-91 }\end{array}$ & $\begin{array}{l}\text { 1. Objawienie i jego przekazywanie za pośrednictwem } \\
\text { katechezy, nr } 36-59 \\
\text { 2. Katecheza w procesie ewangelizacji, } \mathrm{nr} 60-76 \\
\text { 3. Natura, cel i zadania katechezy, } \mathrm{nr} 77-91\end{array}$ \\
\hline $\begin{array}{l}\text { II. Orędzie ewangeliczne, } \\
\text { nr 92-136 }\end{array}$ & $\begin{array}{l}\text { 1. Normy i kryteria przedstawiania orędzia ewangelicznego } \\
\text { w katechezie, nr 94-118 } \\
\text { 2. „Taka jest nasza wiara, taka jest wiara Kościoła”, nr 119-136 }\end{array}$ \\
\hline $\begin{array}{l}\text { III. Pedagogia wiary, } \\
\text { nr 137-162 }\end{array}$ & $\begin{array}{l}\text { 1. Pedagogia Boża, źródła i wzór pedagogii wiary, nr 139-147 } \\
\text { 2. Elementy metodologii, nr } 148-162\end{array}$ \\
\hline $\begin{array}{l}\text { IV. Adresaci katechezy, } \\
\text { nr 163-214 }\end{array}$ & $\begin{array}{l}\text { 1. Przystosowanie do adresata. Aspekty ogólne, nr 167-170 } \\
\text { 2. Katecheza dostosowana do wieku, nr 171-188 } \\
\text { 3. Katecheza w szczególnych sytuacjach, mentalnościach } \\
\text { i środowiskach, nr 189-192 } \\
\text { 4. Katecheza w kontekście społeczno-religijnym, nr 193-201 } \\
\text { 5. Katecheza w kontekście społeczno-kulturowym, nr 202-214 }\end{array}$ \\
\hline
\end{tabular}




\begin{tabular}{|c|l|}
\hline & $\begin{array}{l}\text { 1. Posługa katechetyczna w Kościele partykularnym i jej } \\
\text { pracownicy, nr 217-232 }\end{array}$ \\
2. Formacja do posługi katechetycznej, nr 233-252 \\
partykularnym, nr 215-285 & $\begin{array}{l}\text { 3. Miejsca i drogi katechezy, nr 253-264 } \\
\text { 4. Organizacja duszpasterstwa katechetycznego w Kościele } \\
\text { partykularnym, nr 265-285 }\end{array}$ \\
\hline Zakończenie, nr 286-291 & \\
\hline
\end{tabular}

Analizując strukturę dwóch dyrektoriów należy zauważyć, że część I DCG stała się wprowadzeniem do DOK. Następnie zostały przesunięte kolejne części. Część II DCG stała się częścią I DOK, III DCG - II DOK, IV DCG III DOK, V DCG - IV DOK, a VI DCG - V DOK. Usunięto jedynie suplement poświęcony „Pierwszej spowiedzi i komunii świętej”. Ilościowo DCG zawierało 134, a DOK już 291. Wzrost o ponad 50\% wiąże się nie tylko z objętością tekstu, ale i z nowymi akcentami i nowymi horyzontami katechetycznymi. To, co łączy dwa dyrektoria to inspiracja soborowa. Odwołują się do konstytutywnych tekstów Magisterium Kościoła. Wspólny mają punkt wyjścia dotyczący hierarchiczności fundamentalnych treści. Od miejsca objawienia Bożego, natury katechezy po kryteria głoszenia.

Nowością, którą zawdzięczamy cenionemu prof. Cesare Bissoliemu SDB, są teksty biblijne umieszczone na początku każdej części i każdego rozdziału. Umieszczenie zaraz we wprowadzeniu przypowieści o siewcy (Mk 4,3-8) spowodowało odejście od stylu trochę scholastycznego i doktrynalnego DCG z 1971 r. na rzecz ujęcia bardziej pastoralnego i biblijnego w DOK. Dzięki temu stylowi i zastosowaniu jasnych czterech kryteriów podporządkowanych „hierarchii prawd” otrzymaliśmy klarowne klucze hermeneutyczne do całego dokumentu. Po pierwsze „Objawienie, słowo Boże” jest źródłem katechetycznym. Po drugie, ewangelizacja jest procesem komunikacji. Po trzecie, katecheza jako posługa słowa dokonuje się w ramach procesu ewangelizacji i, po czwarte, celem katechezy jest doprowadzenie katechizowanego do nawrócenia, do wiary osobowej we wspólnocie Kościoła ${ }^{13}$.

Zupełną nowość odnajdujemy w części drugiej DOK z 1997 r. Już zmiana samego tytułu z „Orędzie chrześcijańskie” na „Orędzie ewangeliczne” jest znacząca. Przywołane na początku słowa Jana Pawła II, że „Katecheza będzie zawsze czerpać swoją treść z żywego źródła Słowa Bożego, przekazanego przez Tradycję i Pismo Święte, gdyż «Święta Tradycja i Pismo Święte stano-

\footnotetext{
${ }^{13}$ C. Bissoli, Dyrektorium Ogólne o katechizacji, tłum. J. Kołacz, w: Katecheza Kościoła w świetle Dyrektorium Ogólnego o Katechizacji, Kraków 1999, s. 13-44.
} 
wią jeden święty depozyt Słowa Bożego powierzony Kościołowi»” (CT 27) jasno potwierdzają, że Słowo Boże jest źródłem katechezy, ale dalej mamy znaczące poszerzenie poprzedniego dyrektorium o zagadnienia „źródło i źródła orędzia katechetycznego" (DOK 94-96), o źródła główne i źródła pomocnicze dla katechezy, gdzie każde z nich ma własny język ukształtowany przez doświadczenia wiary. Przechodząc do rozdziału II, który w całości jest nowy (pojawił się w związku z ukazaniem się KKK w 1992 r.), należy zauważyć, że ta część zajmuje się treścią orędzia ewangelicznego (fides quae). Powraca więc konieczność zdefiniowania samego dyrektorium katechetycznego, które z pewnością nie jest - jak tłumaczono wcześniej na język polski - jakimś poradnikiem, prostą instrukcją, czy nawet samymi wytycznymi. Dyrektorium katechetyczne jest oficjalnym dokumentem służącym przekazywaniu całego orędzia ewangelicznego i odnosi się do całości działalności katechetycznej w Kościele katolickim. Katechizm Kościoła Katolickiego jest komplementarnym, choć innym dokumentem wiary, który w naszych czasach stanowi normatywną syntezę całości wiary katolickiej. DOK nie streszcza KKK, lecz ma na celu lepsze zrozumienie i recepcję Katechizmu w praktyce katechetycznej.

Pomimo założenia, że DOK miał być na początku tylko rewizją DCG, to nowości jest dużo. Jest to z pewnością pierwszy w historii dokument, gdzie jeden z rozdziałów jest całkowicie poświęcony inkulturacji. Kościoły partykularne stały się podmiotami katechezy, gdzie podkreślono znacząco rolę biskupów, kapłanów, rodziców, zakonników i zakonnic oraz katechetów świeckich. Jest też opracowanych więcej miejsc i dróg katechezy. Katecheza dorosłych nawet strukturalnie wymieniona na pierwszym miejscu - a potem dzieci i młodzieży stała się punktem wyjścia i pilną potrzebą naszych czasów. Nowością jest również spojrzenie na katechezę w sytuacji pluralizmu i złożoności oraz, co szczególnie ważne dla sytuacji w Polsce, zaproponowano nowy stosunek katechezy do nauczania religii katolickiej w szkole. Zakończenie DOK, które zachęca do intensyfikowania działalności katechetycznej, zwieńcza całą refleksję i ukierunkowuje na ufność w działanie Ducha Świętego oraz skuteczność słowa Bożego, sianego w miłości, z pewnością wypełnia się wielowymiarowo, zarówno w Polsce (chociażby ukazanie się polskiego Dyrektorium katechetycznego Kościoła katolickiego w Polsce w 2001 roku), jak i w wielu innych krajach. Wydaje się, że najbardziej znaczące osiągnięcie DOK z 1997 r. to zharmonizowanie procesu katechezy z KKK oraz pozostanie wiernym Soborowi Watykańskiemu II oraz Nauczycielskiemu Urzędowi Kościoła. 


\section{DYREKTORIUM O KATECHIZACJI Z 2020 R.}

Nowe dyrektorium wydała Papieska Rada ds. Krzewienia Nowej Ewangelizacji, która od 16 stycznia 2013 roku posiada kompetencje administracyjne w sprawach katechezy. Dyrektorium o Katechizacji ${ }^{14}$ zostało zaaprobowane przez papieża Franciszka 23 marca 2020 r. - w dniu liturgicznego wspomnienia Turybiusza de Mogrovejo (1538-1606). DK 2020 podpisali abp Rino Fisichella ${ }^{15}$ i abp Octavio Ruiz Arenas ${ }^{16}$. Wydanie oficjalne jest w języku włoskim.

${ }^{14}$ Papieska Rada ds. KrZewienia Nowej Ewangelizacji, Direttorio per la Catechesi, Libreria Editrice Vaticana 2020. Polską wersję językową wydała Konferencja Episkopatu Polski w wydawnictwie Jedność z Kielc (dalej DK).

${ }^{15}$ Abp Rino Fisichella (ur. w 1951r. w Codogno we Włoszech). Fisichella podpisał 23 marca 2020 r. w Rzymie jako przewodniczący Papieskiej Rady ds. Krzewienia Nowej Ewangelizacji wraz z abp. Octavio Ruiz Arenas w funkcji Sekretarza, trzecie Dyrektorium Katechetyczne (Direttorio per la catechesi) zatwierdzone przez papieża Franciszka. Święcenia kapłańskie przyjął w 1976 r. wyświęcony na biskupa w 1998 r., podniesiony do godności arcybiskupa w 2008 r. W latach 1981-2001 wykładał teologię fundamentalną na Papieskim Uniwersytecie Gregoriańskim. Miał również katedrę teologii fundamentalnej i chrystologii na Papieskim Uniwersytecie Laterańskim, gdzie prowadził wykłady i którego był rektorem w latach 2002-2010. W latach 1993-2010 był rektorem kościoła San Gregorio Nazianzeno, a w latach 1998-2008 biskupem pomocniczym w Rzymie. W latach 2002-2006 był przewodniczącym Papieskiego Instytutu Jana Pawła II dla Studiów nad Małżeństwem i Rodziną (Pontificium Institutum Joannes Paulus II Studiorum Matrimonii ac Familiae). W latach 2008-2010 był przewodniczącym Papieskiej Akademii Życia. Od 30 czerwca 2010 r. jest przewodniczącym Papieskiej Rady ds. Krzewienia Nowej Ewangelizacji. Od 2013 r. jest przewodniczącym Międzynarodowej Rady ds. Katechezy. Jest również członkiem Kongregacji Nauki Wiary, Kongregacji Spraw Kanonizacyjnych, zwaną również Kongregacją do Spraw Świętych, Papieskiej Rady ds. Dialogu Międzyreligijnego, Papieskiej Rady ds. Kultury i Papieskiego Komitetu ds. Międzynarodowych Kongresów Eucharystycznych. Jest autorem wielu pozycji książkowych: La rivelazione: evento e credibilità. Saggio di teologia fondamentale (1985); Dizionario di Teologia Fondamentale (1990); Introduzione alla teologia fondamentale (1992); Lexicon. Dizionario Teologico enciclopedico (1993); La teologia fondamentale. Convergenze per il terzo millennio (1996); Quando la fede pensa (1997); Gli anni santi attraverso le bolle (1999); La teologia tra rivelazione e storia. Introduzione alla teologia sistematica (1999); Gesù di Nazaret, profezia del Padre (2000); La via della verità. Il mistero dell'uomo nel mistero di Cristo (2003); La fede come risposta di senso. Abbandonarsi al mistero (2005); Dio è amore. Commento teologico-pastorale a Deus Caritas Est (2006); Fede e libertà. Dialoghi sullo spirito del tempo (2007); Nel mondo da credenti. Le ragioni dei cattolici nel dibattito politico Italiano (2007); Il sentiero per Emmaus. Commento teologico-pastorale alla Sacramentum Caritatis (2007); Solo l'amore è credibile. Una rilettura dell'opera di Hans Urs Von Balthasar (2007); Identità dissolta. Il cristianesimo, lingua madre dell'Europa (2009); Chiamati ad essere uomini liberi. Conversando con i preti oggi (2009); Salvi per miracolo (2010); La nuova evangelizzazione. Una sfida per uscire dall'indifferenza (2011); La Chiesa nel cammino della storia (2013); I segni del Giubileo (2015); Nuovo commento teologico-pastorale al Catechismo della Chiesa Cattolica (2017); Ho incontrato Paolo VI (2018); Dentro di me il tuo nome. La teologia di Giovanni Paolo II (2020).

${ }^{16}$ Abp Octavio Ruiz Arenas (ur. 21 grudnia 1944 w Bogocie w Kolumbii) podpisał 23 marca 2020 r. w Rzymie jako sekretarz Papieskiej Rady ds. Krzewienia Nowej Ewangelizacji wraz 
Są już tłumaczenia na język hiszpański (oddzielne wydanie dla Ameryki Łacińskiej oraz oddzielne dla Hiszpanii), na język portugalski (wydanie dla Brazylii i Portugalii), na język angielski (wydanie dla USA oraz Zjednoczonego Królestwa), a także na język francuski i polski. Prezentacja nowego dyrektorium miała miejsce na Watykanie 25 czerwca 2020 r. Ze względu na ograniczenia sanitarne związane z epidemią SARS-CoV-2 uczestniczyło w niej wąskie grono dziennikarzy, a transmisja $\mathrm{z}$ tego wydarzenia była prowadzona $\mathrm{w}$ streamingu na kanale „Vatican News” (https://www.youtube.com/c/VaticanNews).

Geneza powstawania trzeciego dyrektorium sięga bezpośrednio ukazania się motu proprio Fides per doctrinam, w którym Benedykt XVI postanowił, że katecheza i jej nauczanie przechodzą z kompetencji Kongregacji ds. Duchowieństwa do Papieskiej Rady ds. Krzewienia Nowej Ewangelizacji. Przeszła do niej również Międzynarodowa Rada ds. Katechezy. Na mocy tego dokumentu (art. 3) Papieska Rada ds. Krzewienia Nowej Ewangelizacji:

$\S 1$. jest odpowiedzialna za krzewienie formacji religijnej wiernych każdego wieku i stanu;

$\S 2$. posiada uprawnienia do wydawania odpowiednich norm, aby nauczanie katechezy było prowadzone w odpowiedni sposób, zgodnie z niezmienną tradycją Kościoła;

$\S 3$. jej zadaniem jest czuwanie, aby formacja katechetyczna była prowadzona prawidłowo, zgodnie z celami i metodologią, według wskazań Magisterium Kościoła;

\footnotetext{
$\mathrm{z}$ abp. Rino Fisichella w funkcji przewodniczącego, trzecie dyrektorium katechetyczne (Direttorio per la Catechesi) zatwierdzone przez papieża Franciszka. Święcenia kapłańskie przyjął w 1969 r., wyświęcony na biskupa w 1996 r., podniesiony do godności arcybiskupa w 2004 r. Ukończył Mniejsze Seminarium Duchowne w Bogocie, następnie studia filozoficzno-teologiczne w Wyższym Seminarium Duchownym w Bogocie. W latach 1977-1979 odbył studia specjalistyczne na Papieskim Uniwersytecie Gregoriańskim w Rzymie, uzyskując stopień naukowy doktora w zakresie teologii dogmatycznej. Po powrocie pełnił następujące funkcje: wikariusza w parafii w Soacha (1969-1972), nauczyciela w Niższym Seminarium Duchownym w Bogocie (1973-1974), wikariusza w parafii de Egipto en Bogotá (1974-1975), ekonoma w de las Aguas (1976). W 1980 r. został rektorem Niższego Seminarium Duchownego w Bogocie, a w latach 1981-1984 r. dołączył do grona moderatorów Wyższego Seminarium Duchownego w Bogocie. W latach 1985-1996 pracował w Kongregacji Nauki Wiary. W latach 1996-2002 był biskupem pomocniczym w Bogocie. W latach 2002-2004 piastował godność biskupa Villavicencio, a po podniesieniu diecezji do rangi archidiecezji, w latach 2004-2007 był pierwszym arcybiskupem Villavicencio. W latach 2007-2011 został mianowany wiceprzewodniczącym Papieskiej Komisji ds. Ameryki Łacińskiej. Od 2011 r. jest Sekretarzem Papieskiej Rady ds. Krzewienia Nowej Ewangelizacji. Jest autorem następujących pozycji książkowych: Jesús, epifanía del amor del Padre: teología de la revelación (1987); La doctrina antropológica de Puebla: hacia un humanismo de comunión y participación (1992); Los presbiteros a la luz de Aparecida y las recomendaciones de la CAL para la formación sacerdotal (2010); América Latina: desafios y esperanzas (2010); Ser misionero en la nueva evangelización (2012).
} 
$\S$ 4. udziela wymaganego zatwierdzenia Stolicy Apostolskiej dla katechizmów i innych pism dotyczących katechezy, za zgodą Kongregacji Nauki Wiary;

§ 5. pomaga urzędom katechetycznym w obrębie Konferencji Episkopatów, śledzi ich inicjatywy dotyczące formacji religijnej oraz wydarzeń o charakterze międzynarodowym, koordynuje ich działania i ewentualnie udziela im niezbędnego wsparcia ${ }^{17}$.

Papieska Rada ds. Krzewienia Nowej Ewangelizacji stała się promotorem dużych konferencji naukowych, które miały miejsce w Ameryce Łacińskiej, USA oraz w Europie i były poświęcone pogłębieniu relacji katecheza a nowa ewangelizacja. W marcu 2015 r. odbyło się w Rzymie spotkanie świata nauki i organizacji pastoralnych poświęcone globalnej sytuacji katechezy. W maju 2015 r. powstał pierwszy tekst roboczy zatytułowany „Katecheza i nowa ewangelizacja”. Podczas II sesji plenarnej Papieskiej Rady, która miała miejsce w Rzymie w dniach 27-29 maja 2015 r., podjęto decyzję o potrzebie rewizji DOK z 1997 r. Powołano wówczas 12 ekspertów, którzy pochodzili z Brazylii, Kolumbii, Meksyku, USA, Chorwacji, Francji, Włoch, Polski ${ }^{18}$, Zjednoczonego Królestwa, Hiszpanii i Ukrainy (wśród nich biskup greckokatolicki, 6 kapłanów, 1 siostra zakonna, 4 ekspertów świeckich [3 kobiety i 1 mężczyzna]). W roku 2016 odbyły się trzy spotkania robocze. W kwietniu 2017 r. rozesłano przygotowany pierwszy tekst roboczy dyrektorium do ponad 100 ekspertów z pięciu kontynentów: kardynałów, biskupów, kapłanów, zakonników i świeckich, którzy reprezentowali nauki biblijne, teologię, katechetykę, liturgikę i teologię pastoralną. Były także konsultowane różne konferencje episkopatów, uniwersytety oraz Międzynarodowa Rada ds. Katechezy. Po uwzględnieniu tych opinii powstała druga wersja robocza dyrektorium. Kolejna powstała we wrześniu 2017 r. po spotkaniu konsultorów Papieskiej Rady poświęconemu sytuacji młodych i religijności ludowej. Czwarta wersja robocza powstała podczas IV sesji plenarnej Papieskiej Rady (27-29 września 2019 r.). Od kolejnego spotkania Międzynarodowej Rady ds. Katechezy (16-17 października 2019 r.) po kolejne procedury konsultacyjne i korekcyjne, po 12 wersjach roboczych i prawie sześciu latach pracy dyrektorium zostało zatwierdzone przez papieża Franciszka ${ }^{19}$.

\footnotetext{
${ }^{17}$ BenedyKT XVI, Lettera Apostolica in forma di Motu proprio Fides per doctrinam (6.01.2013), http://www.vatican.va/content/benedict-xvi/it/motu_proprio/documents/hf_ben-xvi_motu-proprio_ 20130116_fides-per-doctrinam.html (dostęp: 10.06.2020, tł. własne).

${ }^{18} \mathrm{~W}$ tym zespole pracował autor artykułu.

${ }^{19}$ Zob. szerzej: Octavio RuIZ ARENAS, Conferenza Stampa di presentazione del Direttorio per la Catechesi, Vaticano, 25.06.2020, http://www.pcpne.va/content/pcpne/it/attivita/catechesi/ direttorio2020/ruiz.html (dostęp: 25.06.2020).
} 
Trzecie dyrektorium o tytule Direttorio per la Catechesi (Dyrektorium o katechizacji) z 2020 r. zastępuje Direttorio Generale per la Catechesi (Dyrektorium ogólne o katechizacji) z 1997 r. Przypominając pierwsze dyrektorium o nazwie Directorium Catechisticum Generale, zachowuje nie tylko poprzez tytuł bliskie znaczenie, lecz także terminologię swoich poprzedników. Ponadto nowy dokument odnawia i systematyzuje strukturę oraz uwzględnia inne ważne wydarzenia eklezjalne. Uwzględnia synod poświęcony Nowej ewangelizacji dla przekazu wiary chrześcijańskiej, który odbył się w 2012 roku, wraz z opublikowaną po nim adhortacją apostolską papieża Franciszka Evangelii gaudium, a także 25 rocznicę publikacji Katechizmu Kościoła Katolickiego, który stał się w tym czasie nie tylko trwałym punktem odniesienia, ale jednym ze źródeł katechezy.

Nowe dyrektorium katechetyczne składa się ze wstępu, wprowadzenia, trzech części, dwunastu rozdziałów, zakończenia i indeksu tematycznego.

Tabela nr 3. Struktura DK z 2020 r.

\begin{tabular}{|c|c|}
\hline Części & Rozdziały \\
\hline \multicolumn{2}{|l|}{ Wstęp } \\
\hline \multicolumn{2}{|l|}{ Wprowadzenie, nr 1-10 } \\
\hline $\begin{array}{l}\text { I. Katecheza w ewangelizacyjnej misji } \\
\text { Kościoła, nr 11-156 }\end{array}$ & $\begin{array}{l}\text { 1. Objawienie i jego przekaz, nr 11-54 } \\
\text { 2. Tożsamość katechezy, nr 55-109 } \\
\text { 3. Katecheta, nr 110-129 } \\
\text { 4. Formacja katechetów, nr 130-156 }\end{array}$ \\
\hline II. Proces katechetyczny, nr 157-282 & $\begin{array}{l}\text { 5. Pedagogia wiary, nr 157-181 } \\
\text { 6. Katechizm Kościoła Katolickiego, nr 182-193 } \\
\text { 7. Metodologia w katechezie, nr 194-223 } \\
\text { 8. Katecheza w życiu ludzi, nr 224-282 }\end{array}$ \\
\hline $\begin{array}{l}\text { III. Katechizacja w Kościołach } \\
\text { partykularnych, nr 283-425 }\end{array}$ & $\begin{array}{l}\text { 9. Wspólnota chrześcijańska jako podmiot katechezy, } \\
\text { nr 283-318 } \\
\text { 10. Katecheza wobec współczesnych scenariuszy } \\
\text { kulturowych, nr 319-393 } \\
\text { 11. Katecheza w służbie inkulturacji wiary, nr 394-408 } \\
\text { 12. Instytucje zaangażowane w służbę katechezie, } \\
\text { nr 409-425 }\end{array}$ \\
\hline Zakończenie, nr 426-428 & \\
\hline
\end{tabular}


Pierwsza część nowego dyrektorium zatytułowana „Katecheza w ewangelizacyjnej misji Kościoła” to fundament teologiczny dokumentu. „Boże Objawienie i jego przekaz w Kościele otwierają refleksję nad dynamiką ewangelizacji we współczesnym świecie, podejmując jednocześnie wyzwanie misyjnego nawrócenia, które oddziałuje na katechizację" (DK 7). Ta część, zawarta w 146 numerach, ukazuje teologiczny kształt dynamiki głoszenia, w której ściśle wiążą się ze sobą rozpoznanie Bożego działania w sercu każdego człowieka, prymat Ducha Świętego i powszechne otwarcie na każdą osobę. Ukazuje nową ewangelizację jako rzeczywistość wielostronną i dynamiczną, która w swym rozwoju łączy wielorakie możliwości: dawanie świadectwa i głoszenie, słowo i sakrament, zmianę wewnętrzną i przemianę społeczną. Ta część ukazuje głęboki związek kerygmatu i katechezy. Punktem wyjścia nowego dyrektorium jest ukazanie, że możliwe dziś jest, aby „poprzez katechezę każdy mógł odkryć, że warto wierzyć. Wtedy katecheza przestaje być jedynie sposobnością do bardziej harmonijnego wzrostu wiary, lecz przyczynia się do zrodzenia wiary jako takiej, pozwala odkryć jej wielkość i wiarygodność. Dlatego przepowiadania nie można uznać po prostu za pierwszy etap wiary, poprzedzający katechezę, ale raczej za konstytutywny wymiar każdej sposobności do katechezy" (DK 57). W ten fundament teologiczny wpisany jest również katechumenat jako źródło inspiracji dla katechezy i paradygmat papieża Franciszka, aby na katechezie w ramach pewnej progresji potrafić połączyć słuchanie, rozeznanie i oczyszczanie serca, umysłu i zmysłów, pamiętając, iż w centrum każdego procesu katechezy jest żywe spotkanie z Chrystusem. Z pewnością dużym echem odbije się wśród katechetyków i katechetów włączenie w źródła katechezy „piękna”, czyli via pulchritudinis. Każde piękno może być drogą, która pomaga w spotkaniu z Bogiem, ale kryterium jego autentyczności nie jest jedynie estetyczne, co więcej nie może być poddane kryterium użyteczności, ale musi charakteryzować się darmowością. Dyrektorium zachęca nas do postawy krytycznej, aby czujnie odróżnić prawdziwe piękno od form pozornie pięknych, lecz pustych, a wręcz szkodliwych.

Nowością tej części jest również włączenie w nią katechety, który zwyczajowo był w dalszych częściach dyrektorium, a przecież to on urzeczywistnia eklezjalną posługę katechizacji. W pierwszej części Dyrektorium, poza aktualizacją wspomnianych już kwestii zasadniczych, na szczególną uwagę zasługuje rozdział poświęcony formacji, w którym ukazano pespektywy istotne z punktu widzenia odnowienia katechizacji. To katecheta jest świadkiem wiary i strażnikiem pamięci o Bogu. Jest nauczycielem i mistagogiem, który nie tylko mówi o wierze, ale wprowadza w tajemnicę Boga objawionego 
w Jezusie Chrystusie. On jest towarzyszem i wychowawcą tych, którzy zostali mu przez Kościół powierzeni.

Część druga zatytułowana „Proces katechizacji” to wejście w meritum dynamiki katechizacji. W 126 numerach opracowano tu zasadniczy punkt odniesienia dla katechizacji, czyli paradygmat Bożej pedagogii w historii zbawienia, który stanowi inspirację dla pedagogii Kościoła i dla katechizacji jako działania wychowawczego. Poddano reorganizacji i dostosowano do wymogów współczesnej kultury teologiczne kryteria głoszenia ewangelicznego orędzia. Po 25 latach powstania Katechizmu Kościoła Katolickiego zaktualizowano jego wymiar teologiczno-katechetyczny.

Nowością w tej części dokumentu są zagadnienia związane zwłaszcza z komunikacją i narzędziami cyfrowymi w katechezie. Znamienny jest punkt wyjścia tych rozważań: „Kościół jest często przyzwyczajony do komunikacji jednokierunkowej" (DK 214). Dlatego dyrektorium analizuje język, z jego relacyjnymi konotacjami, który stanowi konstytutywny element doświadczenia człowieka. Autorzy mieli świadomość, że katecheza mierzy się z różnorodnością osób, ich kultur, historii i środowisk, ich sposobów i umiejętności rozumienia rzeczywistości. Podkreślili jednak, że katecheza posiada własny, specyficzny język. Trudno oddać w języku polskim włoskie określenie il linguaggio/i linguaggi. Tłumaczymy to jako ,język/języki”, co nie do końca oddaje całe znaczenie tych słów, całego zakresu komunikacji, sposobów komunikacji czy relacji zawartych $\mathrm{w}$ znaczeniu oryginalnym. Odnajdujemy więc w nowym dyrektorium wiele języków wiary eklezjalnej, dzięki którym wierni mogą dysponować wspólnym sposobem porozumiewania się. Nowość dokumentu polega również na tym, że wyjaśnia znaczenie wielu języków i ich ważkość w katechezie. Mamy więc syntetyczne opracowanie zagadnienia: od doświadczenia języków biblijnych w katechezie, języka symboliczno-liturgicznego, języka doktrynalnego, języka performatywnego po uprzywilejowany ostatnio język narracyjny i autobiograficzny. Oczywiście nie brakuje znaczenia języka sztuki w katechezie.

Jeżeli chodzi o trzecie dyrektorium i trzeci porządek adresatów/uczestników katechezy, DCG 1971 rozpoczynało od katechezy dzieci, DOK 1997 zaczynał od katechezy dorosłych, a DK 2020 od katechezy rodzinnej. „Przyszłość człowieka, wspólnoty ludzkiej i kościelnej zależy w dużej mierze od rodziny, która jest podstawową komórką społeczną. Dzięki rodzinie Kościół staje się rodziną rodzin i ubogaca się życiem tych Kościołów domowych" (DK 226) i nie chodzi tu o stwierdzenie czysto socjologiczne czy pastoralne. Chodzi tutaj o doświadczenie katechetyczne, bowiem rodzina jest naturalnym miejscem, w którym wiara może być przeżywana prosto i spontanicznie (zob. DK 227). To, co będzie wymagało dużej zmiany mentalności to użycie zaimka „z” w dostosowaniu 
katechezy do różnych potrzeb, wieku i sytuacji życiowej adresatów. W nowym dyrektorium mamy więc: katechezę z rodziną, katechezę z dziećmi, z młodymi, z dorosłymi, z osobami starszymi, z osobami z niepełnosprawnością, z imigrantami itd. Nie chodzi tutaj o prostą zmianę stylistyczną, ale zaproponowanie innego modelu katechezy, w której jej uczestnicy z przedmiotu zainteresowania staną się aktywnym podmiotem na każdym etapie życia i rozwoju wiary.

Część trzecia, zatytułowana „Katechizacja w Kościołach partykularnych” ukazuje w 143 numerach, w jaki sposób tajemnica Słowa Bożego wciela się konkretnie w życie Kościoła. Mamy tu kontynuację linii poprzednich dyrektoriów o roli Kościołów partykularnych. Nowością tej części dokumentu jest refleksja nad kulturą cyfrową i kwestiami związanymi z bioetyką, będącymi częścią wielkiej debaty naszych czasów. W kwestii kultury cyfrowej dokument nie szuka rozwiązań technicznych do wprowadzenia na katechezę, ale podejmuje wyzwania antropologiczne płynące $z$ postępu nauk i czyni je przedmiotem swego rozeznania. $Z$ jednej strony podkreśla, że katecheta winien pamiętać o wpływie, jaki naukowa mentalność wywiera na ludzi, którzy bywają przekonani do pewnych teorii. $Z$ drugiej natomiast przypomina, że wiele $\mathrm{z}$ tych teorii prezentowanych jest często w sposób pobieżny. Wprowadzając zagadnienia poświęcone katechezie i cywilizacji cyfrowej, kilkakrotnie przypomina, że cyfrowość nie ogranicza się tylko do obecności środków technologicznych, ale narzuca się jako nowa kultura, zmieniająca przede wszystkim język, kształtująca mentalność i ustawiająca nową hierarchię wartości. Dyrektorium ukazuje również, że środowisko cyfrowe jest obszarem samotności, manipulacji, eksploatacji i przemocy, a media cyfrowe mogą narazić na ryzyko uzależnienia i postępującej utraty kontaktu z rzeczywistością. Dyrektorium analizując cywilizację cyfrową tudzież jako zjawisko religijne wskazuje pozytywne cyfrowe wzmocnienie i zachęca do głoszenia Ewangelii i katechizacji w epoce cyfrowej.

Trzecia część dyrektorium kończy się prezentacją instytucji, które pełnią służbę na rzecz katechizacji. Nowością w stosunku do dwóch poprzednich dokumentów jest, iż obecnie to Papieska Rada ds. Krzewienia Nowej Ewangelizacji, a nie Kongregacja ds. Duchowieństwa, sprawuje nadzór nad katechezą oraz katechizacją, aby dzięki temu cała działalność duszpasterska stawała się spójna i skuteczna. Posiada ona uprawnienia do wydawania odpowiednich przepisów, aby nauczanie katechezy było prowadzone w odpowiedni sposób oraz udziela wymaganego zatwierdzenia Stolicy Apostolskiej, dotyczącego katechizmów i innych publikacji katechetycznych. 
$* * *$

Jak można dzisiaj zdefiniować dyrektorium katechetyczne? Dyrektorium (łac. dirigere „kierować”) katechetyczne to normatywny dokument eklezjalny, który zawiera fundamentalne zasady teologiczno-pastoralne zaczerpnięte głównie z dokumentów Soboru Watykańskiego II, Katechizmu Kościoła Katolickiego i innych dokumentów Nauczycielskiego Urzędu Kościoła z zakresu katechezy oraz ogólne wytyczne dla episkopatów w celu opracowania dyrektoriów katechetycznych krajowych, które uwzględniając konkretne warunki, wskażą drogi posługi katechetycznej w Kościołach partykularnych ${ }^{20}$.

Dlaczego ukazują się nowe dyrektoria? Pierwsze z nich, z 1971 r., było odpowiedzią na wielkie wydarzenie eklezjalne, jakim był Sobór Watykański II i jego generalną reformę oraz odnowę. Również następne dokumenty katechetyczne - kontynuując główne przesłanie - odpowiadają na znaki czasu w szybko zmieniającym się świecie. Dla drugiego dyrektorium z 1997 r. odniesieniem były synody, które znaczeniu katechezy poświęcały dużo miejsca, a zwłaszcza adhortacja Jana Pawła II Catechesi tradendae (1979) i ukazanie się Katechizmu Kościoła Katolickiego (1992) odegrały decydującą rolę w nowym opracowaniu celów, treści i zagadnień metodologicznych. Trzecie dyrektorium z 2020 r. to dynamiczne rozwinięcie dwóch wcześniejszych tekstów, z którymi zachowuje ciągłość. Jest to również odczytanie znaków czasu zarówno uwzględniając aspekt czasowo-kulturowy, jak i moralno-religijny. Pierwszy aspekt to zmieniający się coraz szybciej świat z jego kulturą cyfrową i globalizacją kultury. Drugi aspekt jest taki, że odczytujemy znaczące przejawy obecności i działania Ducha Bożego w dziejach - Ducha Świętego, który pobudza tysiące kobiet i mężczyzn, aby głosić Ewangelię. W ciągu kilkudziesięciu lat, które minęły od Soboru Watykańskiego II, Kościół wielokrotnie powracał refleksją do powierzonego mu przez Chrystusa wielkiego posłannictwa. O tym ewangelizacyjnym wymogu mówi dziś ponownie papież Franciszek. Adhortacja Evangelii gaudium nakreśliła kierunek codziennego zaangażowania w ewangelizację, która jest zadaniem każdego wierzącego dla jego zaniechania nie ma zaś usprawiedliwienia. Stąd ścisła więź między ewangelizacją a katechizacją staje się zatem wyróżnikiem nowego dyrektorium.

${ }^{20}$ Jedną z pierwszych prób definicji DOK podaję w: A. KICIŃSKI, Dyrektorium ogólne o katechizacji, w: Stownik katechetyczny, red. J. Gevaert, K. Misiaszek, Wydawnictwo Salezjańskie, Warszawa 2007, s. 233-235. Odpowiedź na pytanie, dlaczego powstają nowe dyrektoria, zob. A. Fossion, Właściwości dyrektorium ogólnego o katechizacji, tłum. A. Królikowska, w: Katecheza Kościoła w świetle dyrektorium ogólnego o katechizacji, red. A. Hajduk, Kraków 1999, s. 67-78. 
Proponuje ono drogę, w której głoszenie kerygmatu i jego dojrzewanie są ze sobą bardzo blisko związane.

Co znaczą posoborowe dyrektoria katechetyczne dla rozwoju myśli i praktyki katechetycznej? Nowe Dyrektoria stanowią kolejne etapy dynamicznej odnowy posoborowej, jaka dokonuje się w katechezie. Nadto są prowadzone studia nad katechezą, które pozwoliły dostrzec konieczność i możliwość nowego usystematyzowania całego procesu katechetycznego o wielkim znaczeniu dla życia Kościoła i procesu dojrzewania ludzi w wierze we współczesnym świecie. Każde Dyrektorium katechetyczne różni odmienny kontekst historyczny i uaktualnione Magisterium oraz uwzględnienie dorobku takich nauk jak: psychologia, pedagogika ogólna i specjalna, dydaktyka, nauki o komunikacji społecznej, w tym edukacja medialna ${ }^{21}$. Ukazanie się trzeciego Dyrektorium o Katechizacji rozpoczyna kolejny etap odnowy, jaka dokonuje się w katechezie i z pewnością jest nowym impulsem dla rozwoju myśli i praktyki katechetycznej.

\section{BIBLIOGRAFIA}

AlBerich, Emilio, Dyrektoria katechetyczne krajowe, w: Słownik katechetyczny, red. J. Gevaert, K. Misiaszek, Wydawnictwo Salezjańskie, Warszawa 2007, s. 226-229.

BENEDYKT XVI, Lettera Apostolica in forma di Motu proprio Fides per doctrinam (6.01.2013), http://www.vatican.va/content/benedict-xvi/it/motu_proprio/documents/hf_ben-xvi_motu-proprio _20130116_fides-per-doctrinam.html (dostęp: 10.06.2020, tł. własne).

Bissoli, Cesare, Dyrektorium ogólne o katechizacji, tłum. J. Kołacz, w: Katecheza Kościoła w świetle Dyrektorium Ogólnego o Katechizacji, Kraków 1999, s. 13-44.

ChARYtAŃsKi, Jan, Katecheza Ewangelii $i$ według Ewangelii. Treść katechezy w świetle dokumentów synodalnych, w: Katecheza po Soborze Watykańskim II w świetle dokumentów Kościoła, red. W. Kubik, tom 2, ATK, Warszawa 1985, s. 48-76.

Chmielewski, Mirosław, Media Education and the New Evangelization. Part One: Media Components and Challenges, „Verbum Vitae” 37(2020), nr 2, s. 407-425.

Fossion, André, Właściwości dyrektorium ogólnego o katechizacji, tłum. A. Królikowska, w: Katecheza Kościoła w świetle dyrektorium ogólnego o katechizacji, red. A. Hajduk, Kraków 1999, s. 67-78.

KICIŃSKI, Andrzej, Dyrektorium ogólne o katechizacji, w: Słownik katechetyczny, red. J. Gevaert, K. Misiaszek, Wydawnictwo Salezjańskie, Warszawa 2007, s. 233-235.

Kongregacja ds. Duchowieństwa, Directorium Catechisticum Generale, Libreria Editrice Vaticana, Vaticano 1971. Wyd. pol. Ogólna instrukcja katechetyczna, tłum. X.E.Sz., „Wiadomości Archidiecezji Warszawskiej” 63(1973), nr 2, s. 37-112.

${ }^{21}$ Pogłębienie tego zagadnienia zob. M. CHMIELEWSKI, Media Education and the New Evangelization. Part One: Media Components and Challenges, „Verbum Vitae” 37(2020), nr 2, s. 407-425. 
Kongregacja DS. Duchowieństwa, Direttorio Generale per la Catechesi, Libreria Editrice Vaticana, Vaticano 1997. Wyd. pol. Dyrektorium ogólne o katechizacji, Poznań 1998.

Papieska Rada ds. Krzewienia Nowej Ewangelizacji, Direttorio per la Catechesi, Libreria Editrice Vaticana, Vaticano 2020. Wyd. pol. Dyrektorium o katechizacji, Kielce 2020.

Ruiz Arenas, Octavio, Conferenza Stampa di presentazione del Direttorio per la Catechesi, Vaticano, 25.06.2020, http://www.pcpne.va/content/pcpne/it/attivita/catechesi/direttorio2020/ ruiz.html (dostęp: 25.06.2020).

SoBóR WATYKAŃSKi II, Konstytucje, dekrety, deklaracje. Tekst polski, red. J. Groblicki, E. Florkowski, S. Jaworski, L. Krawczyk, Poznań 1967 (SOBÓR WATYKAŃSKi II. Konstytucje, dekrety, deklaracje. Tekst polski. Nowe tlumaczenie, red. M. Przybył, Poznań 2002).

\section{ROZWÓJ DYREKTORIÓW KATECHETYCZNYCH PO SOBORZE WATYKAŃSKIM II (1971-1997-2020)}

Streszczenie

Papież Franciszek zatwierdził 23 marca 2020 r. nowe Dyrektorium o Katechizacji, które opracowała Papieska Rada ds. Krzewienia Nowej Ewangelizacji. Pierwsze Directorium Catechisticum Generale z 1971 r. było odpowiedzią na wielkie wydarzenie eklezjalne, jakim był Sobór Watykański II i jego generalną reformę oraz odnowę. Również następne dokumenty katechetyczne kontynuując główne przesłanie - odpowiadają na znaki czasu w szybko zmieniającym się świecie. Dla drugiego Dyrektorium Ogólnego o Katechizacji z 1997 r. odniesieniem były synody, które znaczeniu katechezy poświęcały dużo miejsca, a zwłaszcza adhortacja Jana Pawła II Catechesi tradendae (1979) i ukazanie się Katechizmu Kościoła Katolickiego (1992) miały decydującą rolę w nowym opracowaniu celów, treści i zagadnień metodologicznych. Trzecie Dyrektorium Katechetyczne z 2020 r. to dynamiczne rozwinięcie dwóch wcześniejszych tekstów, z którymi zachowuje ciągłość. Jest to również odczytanie współczesnych znaków czasu.

Dyrektorium katechetyczne to normatywny dokument eklezjalny, który zawiera fundamentalne zasady teologiczno-pastoralne zaczerpnięte głównie z dokumentów Soboru Watykańskiego II, Katechizmu Kościoła Katolickiego i innych dokumentów Nauczycielskiego Urzędu Kościoła z zakresu katechezy oraz ogólne wytyczne dla Episkopatów w celu opracowania dyrektoriów katechetycznych krajowych, które uwzględniając konkretne warunki wskażą drogi posługi katechetycznej w Kościołach partykularnych. Ich rozwój po Soborze Watykańskim II oznacza przechodzenie do kolejnego etapu głoszenia Ewangelii we współczesnym świecie.

Słowa kluczowe: Kościół katolicki; katecheza; teologia pastoralna; edukacja religijna; chrześcijańska edukacja; nowe dyrektorium katechetyczne. 